\title{
Fabrication and characterization of boron free E-glass fiber compositions
}

\author{
Ji-Sun Lee*,**, Tae-Young Lim*, ${ }^{*}$, Yo-Sep Lee*,*, Mi-Jai Lee*, Jonghee Hwang*, Jin-Ho Kim* and \\ Soong-Keun Hyun**
}

*Korea Institute of Ceramic Engineering and Technology, Optic \& Display Material Team, Seoul 153-801, Korea

**Department of Materials Science and Engineering, Inha University, Incheon 402-751, Korea

(Received November 12, 2012)

(Revised December 3, 2012)

(Accepted December 14, 2012)

\begin{abstract}
E-glass fiber is the most widely used glass fiber for reinforced composite materials of aircrafts, automobiles and leisure equipments. But recently researches are being progressed to reduce boric oxide from $8 \%$ to 0 (zero), as is called 'Boron free E-glass', because of increasing material cost, environmental problem, and improving chemical resistance and mechanical properties of E-glass fiber. In this study, we fabricated the bulk glass and fiber glass of 'Boron free E-glass (BF) compositions', and characterized thermal properties and optical properties. 'Boron free E-glass (BF)' was obtained by the melting of mixed batch materials at $1550^{\circ} \mathrm{C}$ for $2 \mathrm{hrs}$ with different $\mathrm{Al}_{2} \mathrm{O}_{3}$ compositions $5 \sim 10 \%$. We obtained transparent clear glass with high visible light transmittance value of $81 \sim 86 \%$, and low thermal expansion coefficient of $4.2 \sim 4.9 \times 10^{-6} /{ }^{\circ} \mathrm{C}$ and softening point of $907 \sim 928^{\circ} \mathrm{C}$. For the chemical resistance test of 'BF' fiber samples, we identified that the higher alumina contents gives the better corrosion resistance of glass fiber.
\end{abstract}

Key words Glass fiber, Boron free, E-glass, Softening point, Thermal expansion coefficient

\section{붕소를 함유하지 않는 E-glass fiber의 제조 및 특성에 대한 연구}

이지선***, 임태영*;, 이요셉*, 이미재*, 황종희*, 김진호*, 현승균**

*한국세라믹기술원 광 - 디스플레이소재팀, 서울, 153-801

**인하대학교 금속공학과, 인천, 402-751

(2012년 11월 12일 접수)

(2012년 12월 3일 심사완료)

(2012년 12월 14일 게재확정)

요 약 E-glass 섬유는 항공기, 자동차, 레져기구의 복합재료 보강용으로 가장 널리 사용되는 유리섬유이다. 그러나 최 근 E-glass 섬유의 원재료비 상승, 환경문제 및 화학적 저항성과 기계적 특성을 향상시키기 위해 산화붕소 함량을 $8 \%$ 에서 0 (제로)까지 감소시키는(소위 'Boron free E-glass'라고 불리는) 연구가 진행되고 있다. 본 연구에서는 'BF(Boron free $\mathrm{E}$ glass) 조성의 벌크유리와 섬유유리를 제조하고, 열적특성 및 광학적특성을 평가하였다. 5 10\%의 서로 다른 알루미나 함량 을 갖는 배치를 $1550^{\circ} \mathrm{C}$ 에서 2시간 용융하여 ' $\mathrm{BF}$ (Boron free E-glass)'가 얻어졌고, 81 86\%의 높은 가시광투과율, $4.2 \sim 4.9 \times$ $10^{-6} \%^{\circ} \mathrm{C}$ 의 낮은 열팽창계수, $907 \sim 928^{\circ} \mathrm{C}$ 의 연화점을 갖는 투명하고 맑은 유리가 얻어졌다. ' $\mathrm{BF}$ ' 섬유 시편에 대한 화학적내 구성 시험에 있어서는 알루미나 함량이 높아질수록 더 좋은 침식저항성을 나타냄을 확인할 수 있었다.

1. 서

유리(glass)에 대한 ASTM(American Society for Testing and Materials)의 정의는 무기질의 용융체를 냉각할 때 결정화하는 일없이 실용상 고체로서 사용할 수 있는 상

\footnotetext{
Corresponding author

Tel: +82-2-3282-2426

Fax: +82-2-3282-7814

E-mail: tylim@kicet.re.kr
}

태까지 응고한 것으로 딱딱하고 부서지기 쉽고, 그 파상 은 조가비상인 것을 말하며[1], 이러한 유리를 가열상태 에서 용융 방사하여 만들어지는 것이 유리섬유(glass fiber) 이다.

유리섬유는 크게 장섬유와 단섬유로 구분되며, 유리 장섬유는 용융유리를 부싱(bushing)이라고 하는 홀(hole) 을 통해서 필라멘트 상태로 연속적으로 인출하면서 고속 으로 감아서 제조하는 것으로, 제품상으로는 얀(yarn)과 로빙(roving)으로 구분되어진다. 유리 단섬유는 통상적으 
로 글라스 울(Glass wool)이라고 불리는데 용융유리를 고압의 공기를 불면서 섬유화 시키는 블로잉(blowing) 방식과 용융유리를 고속으로 회전하는 회전체의 구멍사 이를 통과시켜서 섬유화 시키는 로터리(rotary) 원심력법 에 의해 제조된다[2]. 또한 유리섬유는 특성 및 화학조 성에 따라서 A-Glass, C-Glass, E-Glass, S-glass 그리고 AR-Glass등으로 분류할 수 있다. 이 중에서 현재 가장 많이 사용되고 있는 유리섬유는 E-Glass이다. 그 이유는 E-Glass fiber가 기계적 강도, 전기적 특성, 화학적 특성 등 여러 가지로 균형된 특성을 보유하고 있어서 활용 면 에서 매우 유용하기 때문이다. 전형적인 E-Glass의 화학 조성은 silica $\left(\mathrm{SiO}_{2}\right)$, alumina $\left(\mathrm{Al}_{2} \mathrm{O}_{3}\right)$, calcium oxide $(\mathrm{CaO})$, magnesium oxide $(\mathrm{MgO})$, boric oxide $\left(\mathrm{B}_{2} \mathrm{O}_{3}\right)$ 와 소량의 알칼리 $\left(\mathrm{Na}_{2} \mathrm{O} / \mathrm{K}_{2} \mathrm{O}\right)$ 로 구성되어 있고, $\mathrm{SiO}_{2}$ 함량 중에서 약 6 8\%를 $\mathrm{B}_{2} \mathrm{O}_{3}$ 로 치환함으로써 유리의 용융 온도 및 점도를 낮추는 효과를 나타내며, 이로 인해 알 칼리 $\left(\mathrm{Na}_{2} \mathrm{O}, \mathrm{K}_{2} \mathrm{O}\right)$ 함량이 $1 \%$ 미만으로 매우 낮아서 우 수한 전기적 절연성을 갖는다. 이러한 유리섬유는 넓은 응용범위의 복합재료로서 사용되는데, 섬유강화플라스틱 (FRP)의 보강재료로서 항공기, 자동차 그리고 다양한 레 저용품 등에 널리 사용되고 있다. 그러나, 최근에는 붕소 (boron) 원료 가격의 상승은 물론 공정상의 기술적인 문 제로 인해 붕소 성분의 함량을 줄이거나 아예 붕소 성분 을 함유하지 않는 유리섬유의 개발에 대한 연구가 진행 되고 있다. 이러한 기술적 문제는 첫째, 붕소 원료의 휘 발성으로 인해 환경규제를 만족하는 친환경적인 제품생 산이 필요하다는 것과, 둘째로는 내화학적 특성을 극대화 시키면서 E-Glass의 기계적 물성을 향상시키기 위함이다.

본 연구에서는 붕소 성분을 함유하지 않은 E-glass 조 성의 유리 제조 및 그에 대한 열적, 광학적, 내화학적 특성 데이터를 확립하고자 하였고, 보강섬유용 유리특성 에 가장 큰 영향을 미칠 것으로 판단되는 알루미나 성분 의 함량 변화에 따른 'Boron free E-glass(이하 'BF'라 고 표시)' 조성의 배치를 용융해서 벌크상태의 유리 및 섬유상태의 유리 시편을 제조하였다. 제조된 시편은 열
적 특성평가로서 연화점과 열팽창계수를 측정하였으며, 내화학적 특성으로서 내산성을 확인하였다. 그리고 광학 적 특성평가는 광투과율과 색차를 측정하였다.

\section{2. 실험방법}

유리제품을 만드는데 있어서 가장 중요한 것은 유리화 를 하기 위한 목표화학조성의 결정과 이 조성을 맞추기 위한 원료들의 배합비 선정이다. 원료의 합성비율을 어 떻게 하느냐에 따라서 목표하는 물리적, 화학적 특성을 갖는 유리를 제조 할 수 있으며, 해당 용융온도조건에서 양호한 특성을 갖는 투명한 유리를 제조할 수 있다[3]. 일반적으로 'BF' fiber 조성은 규사, 석회석, 알루미나 등이 주를 이루며 그 배합비에 따라 성질이 달라진다. 본 연구에서 채택한 'BF' 조성의 배합비와 목표유리 조 성을 Table 1에 요약하여 나타내었다. 조성은 붕소를 제 외한 화학성분 중에서 기존에 발표된 기술문헌들에서 나 타나 있는 ' $\mathrm{BF}$ '의 화학조성과는 약간의 차이를 나타내 는 조건에서 배합비를 선정하였으며[4-6], 각각의 배합비 는 배합조성 내에서 알루미나 원료의 투입량을 변화시키 면서, 변화되는 양을 나머지 원료 성분들의 배합비에 따 라 배분하는 방법으로 배합비를 조정하여 시편을 제조하 였다. Fig. 1에 도식된 실험방법에 의해 배합비에 따라 원료를 조합한 후 혼합하여 알루미나 도가니에 넣고 수 직형 전기로에서 $1550^{\circ} \mathrm{C}$ 2시간 동안 용융하였다. 용융된 유리는 로에서 꺼내어 흑연 몰드 위에 부어 시편을 제작 하고, 성형된 시편은 응력제거를 위해 기존의 문헌을 통 해 알려진 'BF' 조성의 서냉온도(annealing temperature) 인 $736^{\circ} \mathrm{C}$ 로 유지된 서냉로에 넣어 2 시간 동안 유지하고 [6], 그 상태에서 그대로 자연로냉시켜 최종 유리샘플을 제조하였다. 아울러서 섬유상태에서의 특성파악을 위해 용융된 유리를 Fig. 2에서 나타낸 것과 같은 별도의 실 험실적 섬유인상장치를 제작하여 단일섬유(single filament) 를 제조하고, 그 특성을 평가하였다.

Table 1

Batch composition of BF (Boron free E-glass) samples

\begin{tabular}{llllllll}
\hline \multirow{2}{*}{ Raw materials } & \multicolumn{2}{l}{ Batch composition (wt\%) } & \multicolumn{2}{l}{ Remarks } \\
\cline { 2 - 5 } & BF-5 & BF-6 & BF-7 & BF-8 & BF-9 & BF-10 & \\
\hline $\mathrm{SiO}_{2}$ & 50.12 & 49.60 & 49.07 & 48.56 & 48.03 & 47.52 & (Target of glass composition) \\
$\mathrm{Al}_{2} \mathrm{O}_{3}$ & 5.00 & 6.00 & 7.00 & 8.00 & 9.00 & 10.00 & $\mathrm{SiO}_{2}: 60.0$ \\
$\mathrm{MgSO}_{4}$ & 8.73 & 8.64 & 8.55 & 8.46 & 8.37 & 8.28 & $\mathrm{Al}_{2} \mathrm{O}_{3}: 72$ \\
$\mathrm{CaCO}_{3}$ & 33.80 & 33.45 & 33.10 & 32.75 & 32.40 & 32.05 & $\mathrm{Na}_{2} \mathrm{O}: 0.8$ \\
$\mathrm{Na}_{2} \mathrm{CO}_{3}$ & 1.14 & 1.13 & 1.12 & 1.11 & 1.09 & 1.08 & $\mathrm{CaO}: 22.5$ \\
$\mathrm{~K}_{2} \mathrm{CO}_{3}$ & 0.34 & 0.34 & 0.33 & 0.33 & 0.32 & 0.32 & $\mathrm{~K}_{2} \mathrm{O}: 0.2$ \\
$\mathrm{Fe}_{2} \mathrm{O}_{3}$ & 0.17 & 0.17 & 0.17 & 0.16 & 0.16 & 0.16 & $\mathrm{MgO}_{2}: 0.8$ \\
$\mathrm{TiO}_{2}$ & 0.67 & 0.66 & 0.66 & 0.65 & 0.64 & 0.63 & $\mathrm{Fe}_{2} \mathrm{O}_{3}: 0.2$ \\
\hline
\end{tabular}




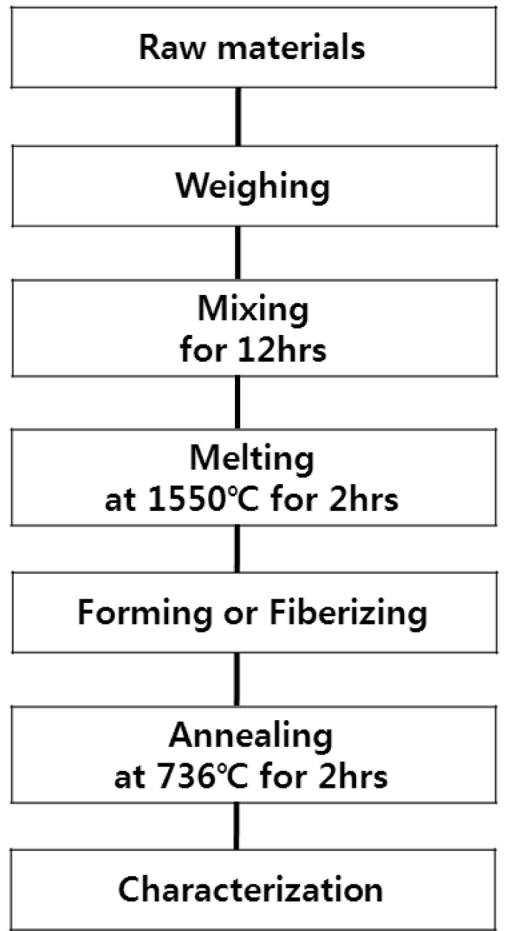

Fig. 1. Experimental procedure for preparing glass samples.

제조된 유리시편에 대해서는 유리의 기본적인 열적특 성을 알아보기 위하여 TMA(Thermomechanical Analyzer: $\mathrm{Q} 400, \mathrm{TA}, \mathrm{USA}$ )를 이용하여 열팽창계수를 측정하였고, 연화점 측정기(SP-3A, ORTON, USA)를 이용하여 연화 점을 측정하였다. 또한 유리화 상태 및 광학적 특성을 알아보기 위하여 유리시편을 $3 \mathrm{~mm}$ 로 일정하게 경면 연 마한 후 UV/VIS/IR Spectrometer(V570, JASCO, JAPAN) 을 이용하여 가시광선 영역에서의 광투과율과 컬러좌표 인 색도를 측정하였다. 그리고 유리조성에 따른 내화학 적 특성은 유리섬유시편을 이용하여 실시하였는데, 각 조성의 glass fiber 시편을 $5 \%$ 염산용액의 $90^{\circ} \mathrm{C}$ 조건에 서 시간경과에 따라 섬유의 표면상태변화를 현미경으로

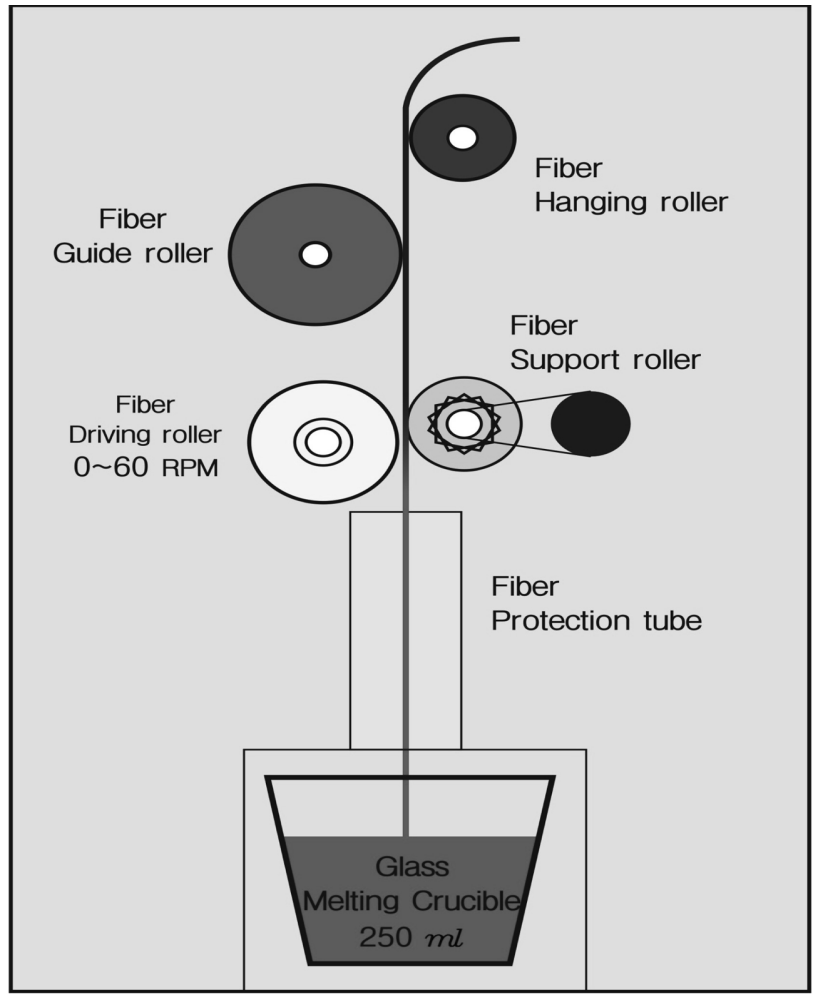

Fig. 2. Experimental fiberizing equipment of glass samples.

관찰하였고, 이를 위하여 Field Emission Scanning Electron Microscope(FE-SEM, JSM 6700, JEOL)를 사용하였다.

\section{3. 결과 및 고찰}

\subsection{Boron free E-glass의 화학조성}

유리가 매우 가는 섬유상이 되면 비표면적이 매우 커 지기 때문에 대기에 의한 풍화, 약품에 대한 침식의 영

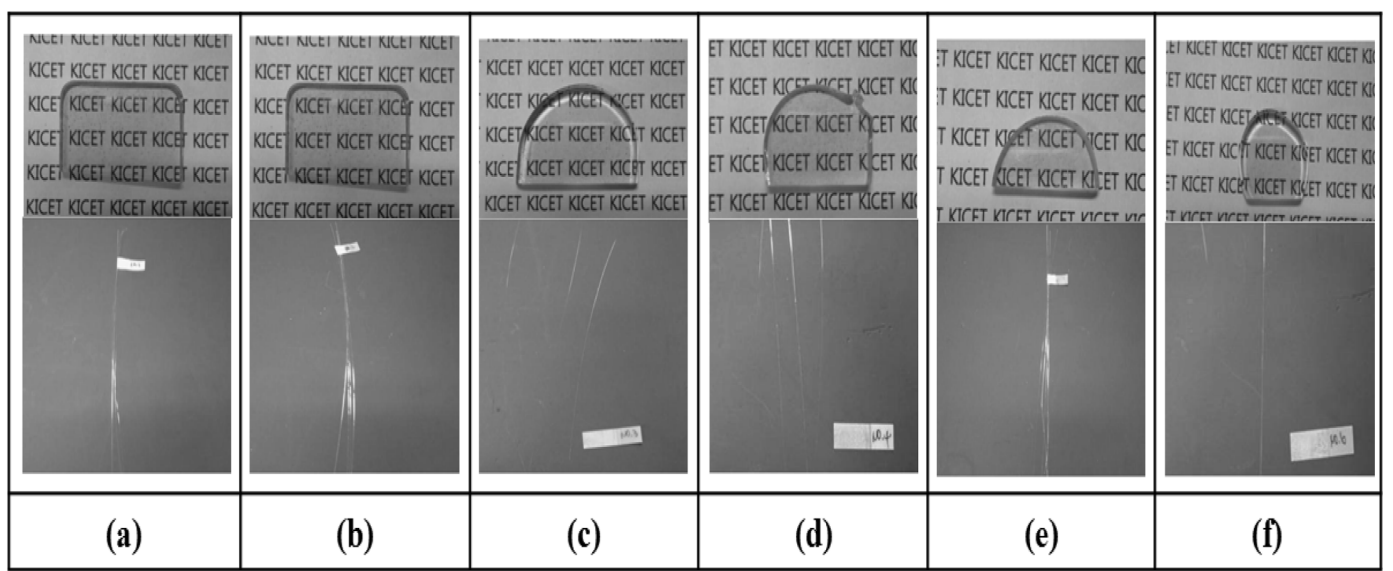

Fig. 3. Photographs of BF (Boron free E-glass) bulk and fiber samples: (a) BF-5, (b) BF-6, (c) BF-7, (d) BF-8, (e) BF-9 and (f) BF-10. 
향이 크므로 화학적 내구성이 좋은 유리조성을 선택하여 야 한다.

그러나 한편 화학적 저항성이 강한 조성을 선택하면 섬유화에 대해 좋지 않은 물리적 성질을 띠기 쉬운 경향 이 생긴다[7].

본 연구에서 채택한 'BF'의 목표조성 및 배합비는 Table 1과 같다. 유리에 있어서 알루미나 $\left(\mathrm{Al}_{2} \mathrm{O}_{3}\right)$ 는 유리 의 작업성, 기계적 특성, 내화학성을 향상시키고, 실투와 열팽창을 감소시킨다[8]. 따라서 ' $\mathrm{BF}$ ' fiber의 화학조성 에 있어서 특성에 가장 큰 영향을 미칠 수 있는 알루미 나 함량을 5 10\%까지 $1 \%$ 씩 변화시키면서 유리의 특 성 변화를 관찰하는 것으로 배합비를 선정하되, 기존에 발표된 'BF' 조성의 범위들을 벗어나는 조건하에서 목 표조성을 정하였다. 기존에 발표된 ' $\mathrm{BF}$ '의 알루미나 목 표조성은 12 15\%의 범위를 갖고 있으므로, 본 연구에 서는 알루미나 함량이 이보다 낮은 범위 하에서 유리조 성을 차별화하여 배치조성기준으로 5 10\%까지 $1 \%$ 씩 변화시키면서 유리의 특성 변화를 관찰하였다. 또한 실 험실적 실험에서는 산화철 $\left(\mathrm{Fe}_{2} \mathrm{O}_{3}\right)$ 원료의 투입이 큰 의 미가 없을 수도 있겠으나 향후 양산 제조시 천연원료 사 용에 따른 불순물로서 산화철 성분의 영향을 파악하기 위해 산화철을 인위적으로 소량 첨가하였다. 혼합된 배 치를 용융한 후 수직전기로에서 꺼내어 흑연몰드에서 성 형하고 $736^{\circ} \mathrm{C}$ 의 고온 서냉로에서 서냉시킨 유리의 경우 에는 Fig. 3(a) (f)의 윗 편 사진에서 나타난 바와 같이 연한 초록빛을 띄는 투명한 유리상태를 나타내었다. 유 리 시편 내에 부분적으로 기포가 포함되어 있는 것이 관 찰되었으나 미용융물이나 실투와 같은 입자들은 발견되 지 않아서 완전한 유리화가 이루어졌음을 판단할 수 있 었다. 유리시편이 연한 초록빛을 띄는 이유는 배치조성 에 포함된 산화철 $\left(\mathrm{Fe}_{2} \mathrm{O}_{3}\right)$ 성분의 영향이라 판단되었으며, 섬유인상장치를 사용해 제조한 유리섬유의 경우에는 Fig. 3(a) (f)의 아래 편 그림에서 나타난 바와 같이 육 안상으로는 백색을 띠는 유리섬유를 제조할 수 있었다.

\subsection{Boron free E-glass의 광투과율 특성}

본 연구에서는 알루미나 함량 변화에 따른 'BF'의 각 조성별로 시편의 유리화 상태 및 용융상태를 파악하기 위해 용융유리 시편을 $3.0 \mathrm{~mm}$ 의 두께로 경면 연마한 후 spectrophotometer를 사용하여 가시광선 파장에서의 광 투과율을 측정하였으며[9], Table 2와 Fig. 4의 그래프에 서 보는 바와 같이 광투과율에 있어서 모든 시편의 가시 광선 투과율 값이 81.2 86.4\%를 나타내어 상업용 투명 판유리에서 나타나는 광투과율 수준과 거의 유사한 값을 나타내었다. 투과율이 시편마다 약간의 차이를 나타내는 이유는 앞에서 언급한대로 시편 내에 부분적으로 존재하
Table 2

Light Transmittance and Chromaticity of BF (Boron free E-glass) samples

\begin{tabular}{lllll}
\hline \multirow{2}{*}{ Sample name } & \multirow{2}{*}{$\begin{array}{l}\text { Light transmittance } \\
(\%)\end{array}$} & \multicolumn{4}{l}{ Chromaticity } \\
\cline { 3 - 5 } & & $\mathrm{L}$ & $\mathrm{a}^{*}$ & $\mathrm{~b}^{*}$ \\
\hline BF-5 & 84.5 & 93.38 & -2.28 & 4.61 \\
BF-6 & 83.5 & 93.83 & -2.29 & 4.76 \\
BF-7 & 86.4 & 94.31 & -1.97 & 4.09 \\
BF-8 & 82.2 & 93.40 & -3.08 & 4.86 \\
BF-9 & 81.2 & 93.05 & -2.07 & 4.18 \\
BF-10 & 83.0 & 93.74 & -1.60 & 4.51 \\
\hline
\end{tabular}

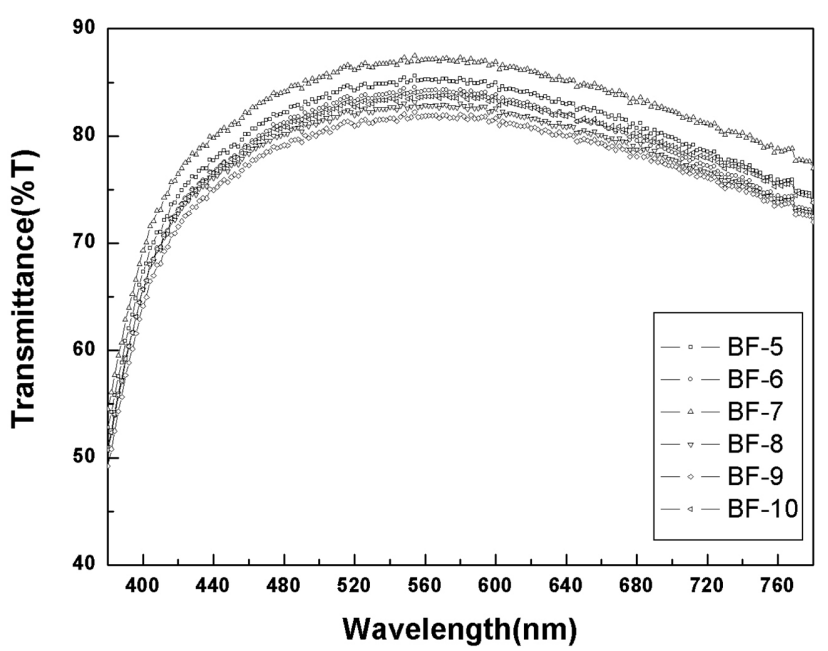

Fig. 4. Light transmittance of BF (Boron free E-glass) samples.

는 기포 및 맥리(cord)와 표면상태에 따라 약간의 차이 를 나타내고 있는 것으로 판단되며, 알루미나 투입량에 따른 투과율 변화의 경향성은 관찰되지 않았다.

\subsection{Boron free E-glass의 색도(Chromaticity) 특성}

유리섬유의 제조에 있어서 중요한 특성은 아니라고 볼 수 있지만 알루미나 투입량 변화에 따라 각 조성별로 만 들어진 유리가 광학적으로 어느 정도 색차를 나타내는지 확인하기 위한 방법으로 색좌표(chromaticity diagram)를 이용해서 칼라의 분포를 측정해 보았으며, 이를 Fig. 5 에 나타내었다. 그림에서 볼 수 있듯이 6개 조성의 샘플 모두 순백색을 나타내는 ' 0 (제로)'의 좌표상에 거의 분포 하고 있었으며, 산화철로 인한 착색으로 인해 좌표 값이 녹색방향으로 약간 치우쳐 있는 것을 확인할 수 있었다. 용융유리에 대한 색차 값의 조성별 차이를 확인하기 위 해 이들 좌표들을 확대해서 분석해본 결과 명도를 나타 내는 $\mathrm{L}$ 값은 93.05 94.31, $\mathrm{b}^{*}$ 에서는 4.09 4.89의 거의 비 슷한 수치를 나타내었고, $\mathrm{a}$ "값에서 -1.60 -3.08로 약간 퍼진 분포 값을 나타내고 있었으나 육안 상으로 구분될 수 있는 편차는 아니어서 큰 문제가 되리라고는 판단되 

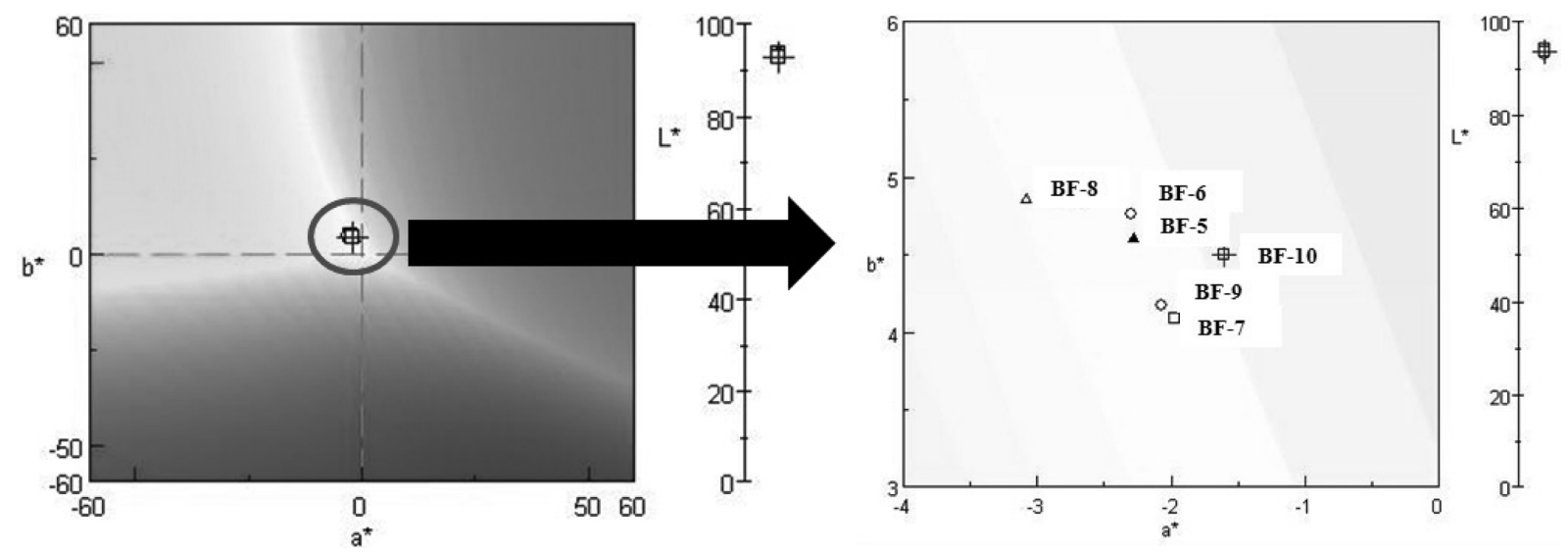

Fig. 5. Chromaticity of BF (Boron free E-glass) samples.

지 않았으며, 알루미나 투입량 증가에 따른 경향성은 관 찰되지 않았다.

\section{2 유리의 열적 특성}

유리섬유의 열적 특성은 복합재료의 보강섬유로서 내 열성에 큰 영향을 미칠 뿐만 아니라 유리의 용융 및 유 리섬유의 섬유화 조건을 결정하는 인자로서도 매우 중요 한 의미를 갖는다. 따라서 유리섬유는 이러한 내열특성 에 따라 일반 E-glass fiber는 $830 ~ 860^{\circ} \mathrm{C}$ 정도의 연화점 을, 기 발표된 기존의 ' $\mathrm{BF}$ ' fiber는 $916^{\circ} \mathrm{C}$, 고강도와 고 내열의 S-glass fiber는 $1,050^{\circ} \mathrm{C}$ 이상의 연화점을 갖는다 [6, 10].

유리의 열적 특성으로서 연화점은 유리의 점도값이 $10^{7.6}$ poise인 온도를 나타내는 값으로서 유리의 작업점 (working point)과 함께 유리의 특성 및 제조공정을 결 정하는 데 중요한 값으로 여겨진다[11]. 제조된 유리샘 플의 조성별 연화점(Softening point)를 측정한 결과는 Table 3에서 보는 바와 같이 $907 \sim 928^{\circ} \mathrm{C}$ 를 나타내었으며, Fig. 6의 그래프에서 나타난 바와 같이 조성상의 알루미 나 함량이 증가할수록 연화점 값이 점차적으로 약간씩 높아지는 것으로 나타났다. 일반적인 E-glass fiber의 연 화점이 $830 ~ 860^{\circ} \mathrm{C}$ 를 나타내므로 이에 비해 알루미나가

Table 3

Thermal properties of BF (Boron free E-glass) samples

\begin{tabular}{lll}
\hline $\begin{array}{l}\text { Sample } \\
\text { name }\end{array}$ & $\begin{array}{l}\text { Softening point } \\
\left({ }^{\circ} \mathrm{C}\right)\end{array}$ & $\begin{array}{l}\text { Thermal expansion } \\
\text { coefficient }\left(\times 10^{-6}{ }^{\circ} \mathrm{C}\right)\end{array}$ \\
\hline BF-5 & 907 & 4.899 \\
BF-6 & 912 & 4.821 \\
BF-7 & 914 & 4.778 \\
BF-8 & 917 & 4.574 \\
BF-9 & 923 & 4.230 \\
BF-10 & 928 & 4.299 \\
\hline
\end{tabular}

$7 \%$ 투입된 $\mathrm{BF}-7$ 은 약 $70^{\circ} \mathrm{C}, 10 \%$ 투입된 $\mathrm{BF}-10$ 은 약 $80^{\circ} \mathrm{C}$ 정도 높은 값이며, 기존의 문헌상에서 나타낸 ' $\mathrm{BF}$ ' 조성의 연화점인 $916^{\circ} \mathrm{C}$ 와 비교해서는 본 실험의 시편에 서 측정된 값이 거의 유사하게 나타남을 알 수 있었으며, 알루미나 투입량이 $9 \%$ 이상인 BF-9과 BF-10의 시편에 서는 약간 높은 값을 나타내었다[12].

또 하나의 열적 특성으로서 유리시편의 열팽창계수를 TMA(thermomechanical analyzer)를 이용해 측정하였으 며[13], 그 결과를 Table 3에 나타내었다. 표에서 볼 수 있듯이 'BF' 시편의 열팽창계수는 조성별로 4.230 4.899× $10^{-6} \% \mathrm{C}$ 를 나타내었다. 알루미나 투입량이 $5 \%$ 로 가장 낮은 $\mathrm{BF}-5$ 는 $4.899 \times 10^{-6} \%^{\circ} \mathrm{C}$ 로 가장 높은 값을 나타내 었으며, Fig. 6의 그래프에서 볼 수 있듯이 조성상의 알 루미나 함량이 증가할수록 열팽창계수 값이 점차적으로 낮아지는 경향을 나타내었다. 일반적인 E-glass fiber의 열팽창계수가 $4.9 \sim 6.0 \times 10^{-6} \rho^{\circ} \mathrm{C}$ 정도이고, 기존의 문헌상 에서 나타낸 'BF' 조성의 열팽창계수 $6.0 \times 10^{-6} \rho^{\circ} \mathrm{C}$ 와 비 교해 볼 때 본 실험에서의 시편이 약간 낮은 값을 나타 내고 있음을 알 수 있었다[14]. 유리에서는 일반적으로

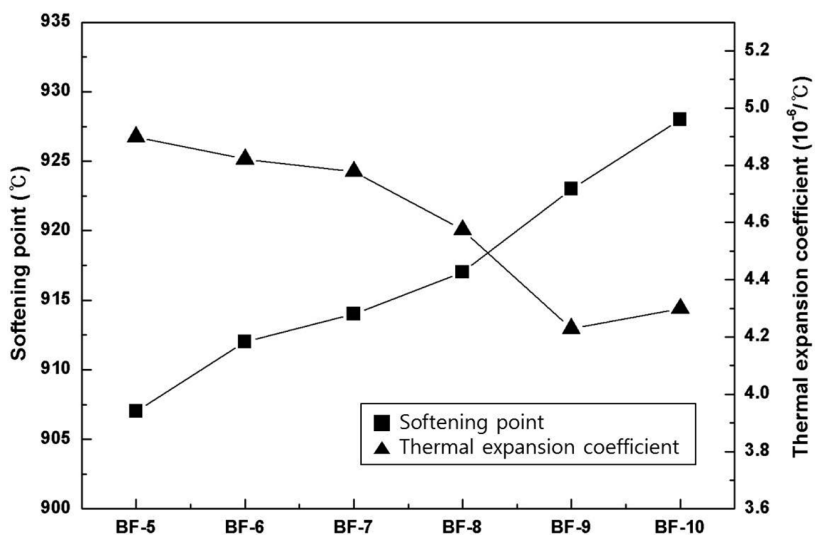

Fig. 6. Softening point and thermal expansion coefficient graphs of BF (Boron free E-glass) samples: (a) BF-5, (b) BF-6, (c) BF-7, (d) BF-8, (e) BF-9 and (f) BF-10. 
열팽창계수가 작을수록 열적변화에 대한 내열충격성이 크며, 내열충격성은 유리가 깨지는 온도차(T)로 표시되 고, 아래 식에서와 같이 표현된다[15].

$$
\mathrm{T}=\sigma(1-v) /(\mathrm{E} \bullet \alpha) \cdot \mathrm{S}
$$

( $\sigma$ : 파괴응력(인장강도), $\mathrm{v}$ : 푸아송비(Poisson's ratio), $\mathrm{E}$ : 영률(Young's modulus), $\alpha$ : 선팽창계수, $\mathrm{S}$ : 시험편의 모양에 따라 달라지는 값)

따라서, 열적 특성면에서 봤을 때 큰 차이는 아니지만 열팽창계수가 낮고, 연화점이 높은 것은 유리의 내열성 을 높인다는 면에서는 바람직한 특성이 될 수 있기 때문 에 본 실험에서 적용한 배합비들 중에서 알루미나 투입 량이 $9 \%$ 이상인 BF-9과 BF-10의 시편에서는 기존의 'Boron free E-glass'와 비교해서 열적 특성상으로는 충 분히 양호한 특성을 나타낼 수 있을 것으로 판단되었다.

\subsection{Boron free E-glass의 내화학특성}

일반적으로 섬유유리는 벌크(bulk) 상의 유리에 비해 비표면적이 크기 때문에 산 및 알칼리에 의한 침식성이 크다. 따라서 이러한 특성을 보완하기 위해서 시멘트 및 콘크리트의 보강용으로 사용되는 유리섬유는 AR(Alkali Resistant) glass fiber 라고 해서 지르코니아 $\left(\mathrm{ZrO}_{2}\right)$ 성분 이 함유된 특수한 조성의 유리섬유를 사용하고 있다 [14]. 반면에 일반적인 E-glass의 조성의 유리섬유는 산 (acid)에 용해되기 쉬운 성분이 포함되어 있어서 산과 접
촉되었을 때 유리섬유 표면에 균열이 발생하며, 유리섬 유의 전체적인 부식을 유발하고, 따라서 이러한 유리섬 유의 부식은 보강강화용으로써 복합재료 전체의 물성 저 하를 초래하는 결과를 나타낸다.

본 실험에서는 'BF' fiber의 내화학특성 특성을 파악 하기 위해서 Fig. 2에 나타낸 것과 같은 유리섬유인상장 치를 통해 각 조성별로 유리섬유를 제조하고, $5 \%$ 염산 용액의 $90^{\circ} \mathrm{C}$ 조건에서 각각의 섬유시편들을 침적시켰다 가 20 분 3 시간까지 일정시간마다 샘플을 채취하여 섬유 표면상태의 변화를 현미경으로 관찰하였으며, 이 가운데 서 대표적으로 알루미나 투입량이 각각 $5 \%, 7 \%, 9 \%$ 인 BF-5, BF-7, BF-9의 3가지 종류의 유리섬유 시편에 대해서 각각 20 분, 40 분, 60 분, 120 분, 180 분 용액침적 후의 사진을 Fig. 7에 나타내었다. 사진에서 볼 수 있듯 이 침적 전 섬유의 표면상태는 비교적 깨끗한 표면 상태 를 나타내었으나 20분 침적 후부터 표면에 미세한 균열 이 발생함을 관찰할 수 있었다. 먼저 BF-5 시편의 상태 를 관찰해보면 60 분이 경과되면서부터 외부의 1 차 표면 층이 완전히 벗겨지고, 120 분 이후부터는 연속적인 섬유 표면의 박리로 인해 여러 개의 두께층이 드러나 있는 것 을 볼 수 있었으며, 180 분 이후에는 심한 침식으로 인해 섬유의 형상이 거의 붕괴됨을 관찰할 수 있었다. 반면에 알루미나의 함량이 약간 높은 BF-7 시편을 보면 유사한 변화를 나타내고는 있으나 상대적으로 침식상태가 덜 함 을 알 수 있었고, 알루미나 투입량이 $9 \%$ 인 BF-9 시편 에 있어서는 60 분 경과 후 까지도 부분적인 침식만이 진행되는 것을 볼 수 있었고, 180 분 경과 후 시편에서만

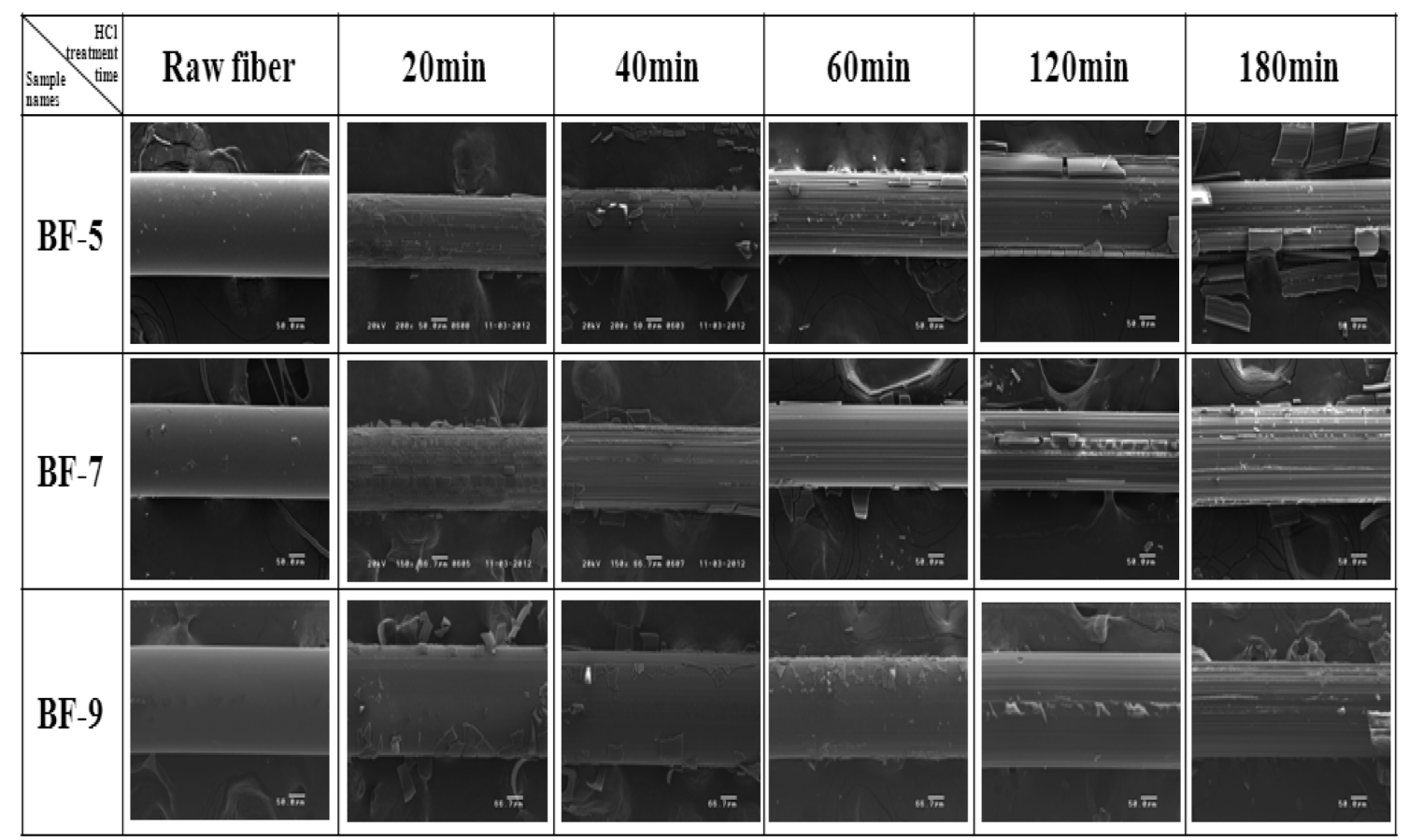

Fig. 7. SEM Photographs of $\mathrm{BF}$ (Boron free E-glass) fiber samples in $5 \% \mathrm{HCl}$ at $90^{\circ} \mathrm{C}$. 
섬유표면의 박리를 관찰할 수 있어서 BF-5 및 BF-7 시 편에 비해서는 훨씬 침식이 덜 진행되었음을 확인할 수 있었다. 따라서 본 'BF' 조성에 있어서 알루미나의 함량 증가에 따라 산에 의한 유리섬유의 내침식성은 크게 향 상됨을 파악할 수 있었다.

\section{4. 결 론}

복합재료의 보강섬유로 널리 사용되고 있는 기존의 Eglass fiber가 갖고 있는 원재료비 상승, 환경적 문제, 특 성 향상 등을 목적으로 붕소(boron) 성분을 함유하지 않 는 'BF(Boron free E-glass)' 조성을 선정하여 실험실적 용융실험 및 특성측정을 실시하였다. 조성상 유리섬유의 특성에 큰 영향을 미칠 수 있는 알루미나의 투입량을 $5 \sim 10 \%$ 까지 변화시키면서, 각 조성의 배치를 $1550^{\circ} \mathrm{C}$ 에 서 2시간 용융한 결과 투명한 유리를 얻을 수 있었다. 용융유리의 가시광투과율은 81 86\%로 알루미나의 투입 량에 따라 큰 변화가 없었으며, 열적특성인 연화점은 $907 \sim 928^{\circ} \mathrm{C}$ 로 알루미나의 증가에 따라 상승하고, 열팽창 계수는 $4.2 \sim 4.9 \times 10^{-6} \rho^{\circ} \mathrm{C}$ 로 알루미나의 증가에 따라 감 소하는 경향을 나타내었다. 또한 실험실적으로 제조한 유리섬유의 $90^{\circ} \mathrm{C}$ 염산용액에서의 내산성 실험에서는 침 적시간이 경과됨에 따라 섬유표면에 미세한 균열층 및 박리현상이 발생하는 것을 관찰할 수 있었고, 알루미나 함량이 높을수록 내침식성이 우수함을 확인할 수 있었다. 이로서 본 실험에서 채택한 'BF' 조성의 유리는 양호한 용융상태와 기존의 'BF' 조성에 비해 우수한 열적 특성 을 나타냄으로써 향후 섬유화에 대한 조건별 최적화 실 험 및 양산 제조를 위한 추가 검토를 거쳐 충분히 실용 화가 가능할 수 있을 것으로 판단되었다.

\section{감사의 글}

본 연구는 한국세라믹기술원 '세라믹산업섬유실용화센 터 구축사업'으로 수행되었습니다.

\section{참 고 문 헌}

[1] B.H. Kim, "Glass technology", Vol. 3 (Chungmoon Gak, Seoul, Korea, 2009) p. 10.

[2] S.W. Choi, "Glass fibers", Korea Institute of Science and Technology Information (2010) 2.

[ 3 ] T.Y. Lim, S.S. Jung, J. Hwang and J.H. Kim, "A study on the fabrication of soda-lime glass by using refused coal ore and its properties", Journal of the Korean Crystal Growth and Crystal Technology 20(1) (2010) 44.

[4] J.F. Sproull, "Fiber glass compositions", U.S. Patent 4,542,106, 17 Sept (1985).

[ 5 ] W.L. Eastes, "Boron-free glass fibers", U.S. Patent 5,789,329, 4 Aug (1998).

[6] F.T. Wallenberger, J.C. Watson and H. Li, "Glass fibers", Vol. 21 (ASM Handbook, 2001) p. 28.

[ 7 ] B.H. Kim, "Glass technology", Vol. 3 (Chungmoon Gak, Seoul, Korea, 2009) p. 430.

[ 8 ] H.J. Jung, "Fusion ceramic materials (text book for high school)", Vol. 1 (Ministery of Education Science and Technology, 2003) p. 60.

[9] J.H. Kim, H.H. Jung, J. Hwang, Y. Cho and T.Y. Lim, "Properties of $\mathrm{TiO}_{2}$ thin films fabricated with surfactant by a sol-gel method", Journal of the Korean Crystal Growth and Crystal Technology 20(6) (2010) 268.

[10] F.T. Wallenberger, R. Naslain, J.B. Macchesney and H.D. Ackler, "Advanced Inorganic fibers", Vol. 1 (Kluwer Academic Publishers, London, 1999) p. 137.

[11] B.H. Kim, "Glass technology", Vol. 3 (Chungmoon Gak, Seoul, Korea, 2009) p. 380.

[12] T.Y. Lim, H.W. Ku, J. Hwang J.H. Kim and J.K. Kim, "A study on the fabrication of foamed glass by using refused coal ore and its physical properties", Journal of the Korean Crystal Growth and Crystal Technology 21(6) (2011) 268.

[13] F.T. Wallenberger, J.C. Watson and H. Li, "Glass fibers", Vol. 21 (ASM Handbook, 2001) p. 28.

[14] H.J. Jung, "Fusion ceramic materials (text book for high school)", Vol. 1 (Ministery of Education Science and Technology, Korea, 2003) p. 193.

[15] F.T. Wallenberger, R. Naslain, J.B. Macchesney and H.D. Ackler, "Advanced inorganic fibers", Vol. 1 (Kluwer Academic Publishers, London, 1999) p. 147. 